\title{
Forest Environmental Inventory: Assessment of Site Index Parameter of Uneven Aged Plots of Tectona Grandis (f. linn) in a Forest Reserve
}

\author{
Egbuche Christian. Toochi ${ }^{1}$, Nwaigbo L.C ${ }^{2}$ and Ina Toochi ${ }^{1}$
}

\begin{abstract}
The basic physical resources in lands and timber growing upon is "Site" which expresses the capacity of a given area of land to grow timber or other vegetation available timber resources are to a large extent, related to the total reserved area for forestry, and to some extent, to area outside the reserve forest. The assessment of site index parameter of uneven aged plots of Tectona grandis (F. Linn) in a Forest Reserve has positioned a new concept of research in understanding forest canopy, forest health and management regimes. Forest reserves and management regimes have been a focus to understand forest basal areas, volume estimation and site index in the face of changing global climate. Various estimations were conducted in a forest reserve that includes basal area, volume estimation and site index of uneven aged plots of Tectona grandis. The field evaluation focused on the growth parameters such as Total Height, and dominant Height, Crown diameter, Crown length and Diameter at Breast Height to estimate the Basal Area, Volume and Site Index of 3, 4 and 5 years plots of Teak. Six plots of same age were measured out in a plot size of $15 \times 10 \mathrm{~m}$ using the measuring tape. It was gathered that the total Basal Area of the six plots of two each of 3,4 and 5 years Tectona grandis recorded about $1.41121 \mathrm{~m} 2$ and the total volume over bark of the six plots recorded about $8.40233 \mathrm{~m} 3$. The true volume of the plot was estimated by multiplying the cylindrical volume by the form factor. Field results showed that the mean true volume of the plots were $30.36 \mathrm{~m} 3$ for plot 1 and 2 (3 years), $38.25 \mathrm{~m} 3$ for plot 2 and 3 (4 years), $36.73 \mathrm{~m} 3$ for plot 5 and 6 ( 5 years). Forest field measurement and inventory showed that there were no tending practices in the forest reserve and as such need the intervention of both the government and regional community.
\end{abstract}

Keywords - Site index parameter, Forest reserve, uneven aged plots, Tectonia grandis and forest reserve inventory.

\section{INTRODUCTION}

The basic concern in this research is identified in understanding that basic physical resources in lands and timber growing upon is "Site" which expresses the capacity of a given area of land to grow timber or other vegetation available timber resources are to a large extent, related to the total reserved area for forestry, and to some extent, to area

${ }^{1}$ School of Agriculture and Agricultural Technology Department of Forestry and Wildlife Technology, The Federal University of Technology Owerri Imo State, Nigeria

${ }^{2}$ Faculty of Agriculture, Abia State University Uturu, Abia State, Nigeria, Email: ctoochi@yahoo.co.uk /dccenvironment@gmail.com

Phone: $+234-8068093593$ or $234-7082646804$ outside the reserve forest. Site as defined by [1] [2] is "area, considered as to its ecological factors with reference to capacity to produce forests or other vegetation; the combination of biotic, climatic, and soil conditions of an area". Trees of the same species may react differently to a given soil at different ages. Tree height growth has been considered most practical, consistent and generally useful indicator of forest-site quality. Height growth of trees in the dominant canopy is very sensitive to differences in site, strongly correlated with volume growth, and weakly related to stocking and species composition. The dynamic of reserved areas are being greatly depleted in view of the escalating, demand for wood and wood products in the country [3] [4]. Forests land cover at least one hectare with trees established through natural regeneration, reforestation or seedling that have the potentials to reach a height of at least $5 \mathrm{~m}$ and attained 30\% tree crown cover [5] [6]. Most plantations in Nigeria are established as a result to natural disasters and other uses such as water shed protection, climate amelioration etc. [7] [8]. In order to be able to get the best from these, a good knowledge of their growth and growth variables need be studied.[9] stated that tree growth and stem from development follows general laws of patterns of growth that are hereditary. It is further explained that this basic pattern may be modified by many environmental factors and silvicultural practices. Forest inventory is the systematic collection of data forest information for assessment analysis. It determines the location of timber and estimates its quality by species, product potential, size quality or other characteristics. According to [10] [11], forest inventory provides data needed for the construction of yield and growth model which may be used together with forestry. An important requirement for development for sustainable typical forest management is the collection of good quality forest growth and development data through continuous forest inventory in order that the sustainability of forest ecosystem may be properly determined. A forest growth and yield model portrays the development of tree as they increase in age or as time changes. There is wide spread concern for regeneration and conservation of forest, with a view to meeting the ever growing demand for wood and wood products. Of the 130 existing species in plantation and specie trials, Gmelina arborea and Tectonia grandis have been found to be most successful in many areas. They occupy more than $85 \%$ of the 
planted areas now rapidly replacing the natural rainforest in Nigeria [12] [15] [16]. Moreover, Tectonia grandis in particular is regarded as very suitable specie for the rapid reproduction of large volumes of timber; fuel wood and poles of uniform and desirable quality.

\section{A. Statement of the Problem}

There is an increasing demand and pressure on almost countries wood resource base. The pressure results from human activities which include forest clearance for agriculture, development of infrastructural facilities and oil exploitation. Thus, from the fore-going, the main research question is that what ways does total height; crown diameter, over bark volume and diameter at breast height (DBH) affect yield assessment?

\section{Methodology AND RESUltS}

\section{A. Study Area Description}

The study area is Ohaji/Egbema forest reserve. The plantation is located at the outskirt of Owerri. It is on a latitude of $5^{0} 29^{\prime} \mathrm{N}$ and $7^{0} 2^{\prime} \mathrm{E}$ of the equator. It has an elevation of about $45 \mathrm{~m}$ above sea level and is bounded by Egbema community.

\section{B. Climate and Vegetation}

Ohaji/Egbema forest reserve is characterized by dry and rainy season. The dry season lasts from late October to early March while the rainy season has two peak periods, which are July and September. Average annual rainfall is about $1550.5 \mathrm{~mm}$ with a humidity of $70.75 \%$ during the dry season. The monthly average for dry season is less than $25 \mathrm{~mm}$. the temperature of the area is usually $26^{\circ} \mathrm{C}$ to $27^{\circ} \mathrm{C}$ but drops to $24^{0} \mathrm{C}$ to $25^{0} \mathrm{C}$ in the night or during harmattan season. The plantation has dense and closer canopy but there are few plants mostly Chromonelaodorata, other plants include Tectona grandis seedlings, Nauclea diderichii, Gmelina arborea, etc. Other plants include Aspila Africana and dispersed stands of Casuarina spp. The study site is in Ohaji/Egbema forest reserve and was established at different years (uneven-aged plantation). They were established in 2008, 2009, and 2010. The establishment of the plantation was through direct planting of stumps using a spacing of $2 \mathrm{~m} \times 2 \mathrm{~m}$. The main purpose of the establishment of the plantation was for teaching and research work. Teak (Tectona grandis) is dominant with stands of Gmelina arborea.

\section{Sampling and Data Collection}

The data were collected on stands of uneven-aged Teak plantation. A total of 6 plots of $10 \mathrm{~m} \times 15 \mathrm{~m}$ dimension were randomly selected, each plots has varying numbers of Teak trees on which measurement were to be taken. The exercise started with the demarcation of each plot boundary while poles at the four corner of each boundary after the measurement of the parameters for each tree in a plot was taken.

\section{Tree Parameter Measuremen}

The following parameters were collected on tree within each sample plot. Complete enumeration was carried out on each plot where all trees were measured for diameter at breast height $(\mathrm{DBH})$. The diameter at breast was measured at 1.3 along the bole of each tree.

a. Diameter at the base, middle and the top of all trees (in $\mathrm{cm})$ was also taken.

b. Crown diameter of trees (in meters) was taken by measuring from south to north of the crown and also from west to east.

c. The two distance were added together and divided by 2 (two).

a. Total height (in meter) and merchantable height.

b. Crown length (in meter) this is the distance between the crowns to the top of the tree.

\section{DATA ANALYSIS}

\section{A. Descriptive Analysis of Data}

The data obtained on the field where DBH, total height, crown diameter and diameter at the top, middle and base. For the analysis of the data, the six (6) individual plots of 3, 4 and 5 years where taken into account. For the establishment of the basal area of the plots, individual stands where considered.

\section{B. Site Index Estimation}

Site index was obtained by measuring girth of the largest 100 trees their respective heights will be plotted against DBH,

[1] To obtain true volume, whereby there can be estimate that cylindrical volume $=$ height $\times$ basal area. Therefore, true volume $=$ cylindrical volume $\times$ form factor. An example of site index equation is:

$\ln s=H_{d} b_{1}\left(A^{1}-A_{i}^{1}\right)$

Where;

$\mathrm{S}=$ site index.

$\mathrm{A}_{\mathrm{i}}=$ index age.

$\mathrm{H}_{\mathrm{d}}=$ height of dominant and co-dominant trees.

$\mathrm{A}=$ stand age.

According to [16], site index is a tool to determine the relative productivity of a particular site or location. Site index is the height of a "free to grow" tree of a given species at a base age on the site of interest. Common base ages include 25 , 50, and 100, depending on the lifespan and common management practices for that species.

\section{RESUlts AND Discussion}

\section{A. Site Index Estimation}

Site index was obtained by measuring girth of the largest 100 trees their respective heights was be plotted against DBH, $\mathrm{T}$ obtain true volume, but we can estimate that cylindrical volume $=$ height $\times$ basal area. Therefore, true volume $=$ cylindrical volume $\times$ form factor.

The cylindrical volume of the 6 plots

Total height of plot $1=253.76 \mathrm{~m}$ 
Total height of plot $2=273.36 \mathrm{~m}$

Total height of plot $3=271.85 \mathrm{~m}$

Total height of plot $4=262.85 \mathrm{~m}$

Total height of plot $5=309.16 \mathrm{~m}$

Total height of plot $6=249.90 \mathrm{~m}$

This section of the study analyses data obtained on yield, $\mathrm{DBH}$, total height and crown diameter from an uneven Tectona grandis plantation of 3, 4, and 5 years measured in six (6) different plots (two each) of $10 \mathrm{~m} \times 15 \mathrm{~m}$ that where randomly chosen for this experiment. The data obtained from the field differences in DBH, total height, and crown diameter. The results of the data obtained are presented in table 1, table 2 and table 3 while DBH results obtained on yield is shown in fig.3, fig.4 and fig. 5 respectively.

TABLE I

Growth PARAMETERS (TECTONIA GRANDIS) AGE 3 YeARs EVALUATEd IN PLOT A AND PLOT B

Plot A

Plot B

\begin{tabular}{|r|c|r|r|r|r|}
\hline Tree No & $\begin{array}{c}\text { Total Height } \\
(\mathrm{m})\end{array}$ & $\mathrm{D}_{\mathrm{b}}(\mathrm{cm})$ & Tree No & $\begin{array}{l}\text { Total Height } \\
(\mathrm{m})\end{array}$ & $\mathrm{D}_{\mathrm{b}}(\mathrm{cm})$ \\
\hline 1 & 6.10 & 10.47 & 1 & 5.78 & 9.47 \\
\hline 2 & 4.60 & 10.22 & 2 & 6.43 & 10.93 \\
\hline 3 & 7.50 & 11.98 & 3 & 8.72 & 12.56 \\
\hline 4 & 5.30 & 8.43 & 4 & 6.15 & 10.65 \\
\hline 5 & 5.70 & 7.73 & 5 & 6.75 & 11.83 \\
\hline 6 & 6.80 & 8.40 & 6 & 6.00 & 9.96 \\
\hline 7 & 6.75 & 9.10 & 7 & 10.45 & 14.50 \\
\hline 8 & 5.50 & 9.30 & 8 & 9.05 & 12.56 \\
\hline 9 & 7.50 & 10.73 & 9 & 6.90 & 10.46 \\
\hline 10 & 5.50 & 9.55 & 10 & 8.30 & 9.80 \\
\hline 11 & 6.50 & 8.34 & 11 & 9.58 & 14.65 \\
\hline 12 & 6.90 & 9.26 & 12 & 8.62 & 12.54 \\
\hline 13 & 4.20 & 8.08 & 13 & 7.92 & 10.36 \\
\hline 14 & 6.20 & 9.00 & 14 & 8.30 & 15.28 \\
\hline 15 & 8.90 & 11.84 & 15 & 5.80 & 9.80 \\
\hline 16 & 6.75 & 11.04 & 16 & 6.40 & 9.01 \\
\hline 17 & 8.35 & 11.08 & 17 & 8.01 & 12.54 \\
\hline 18 & 5.70 & 9.61 & 18 & 8.50 & 15.88 \\
\hline 19 & 5.25 & 9.10 & 19 & 5.20 & 8.53 \\
\hline 20 & 8.85 & 14.80 & 20 & 6.00 & 9.96 \\
\hline 21 & 6.75 & 11.04 & 21 & 8.20 & 10.57 \\
\hline 22 & 5.78 & 9.47 & 22 & 5.30 & 11.27 \\
\hline 23 & 6.43 & 10.93 & 23 & 8.30 & 10.50 \\
\hline 24 & 6.00 & 10.73 & 24 & 6.10 & 10.47 \\
\hline 25 & 7.70 & 16.23 & 25 & 4.60 & 10.22 \\
\hline 26 & 7.55 & 9.87 & 26 & 7.50 & 11.98 \\
\hline 27 & 7.50 & 11.98 & 27 & 5.30 & 8.43 \\
\hline 28 & 8.55 & 14.32 & 28 & 7.50 & 11.98 \\
\hline 29 & 5.75 & 10.47 & 29 & 8.55 & 14.32 \\
\hline 30 & 6.20 & 11.24 & 30 & 5.75 & 10.47 \\
\hline 31 & 6.00 & 9.96 & 31 & 6.20 & 11.24 \\
\hline 32 & 8.20 & 10.57 & 32 & 6.00 & 9.96 \\
\hline 33 & 5.30 & 11.27 & 33 & 8.20 & 10.57 \\
\hline 34 & 9.50 & 12.60 & 34 & 5.30 & 11.27 \\
\hline 35 & 6.50 & 10.50 & 35 & 9.50 & 12.60 \\
\hline 36 & 8.20 & 11.74 & 36 & 6.50 & 10.50 \\
\hline 37 & 5.50 & 9.55 & 37 & 8.20 & 11.74 \\
\hline 38 & 7.50 & 11.98 & 38 & 7.50 & 11.98 \\
\hline $\mathbf{D}$ & & & & & \\
\hline
\end{tabular}

D $_{\text {b - Diameter at Breast Height (DBH) }}$

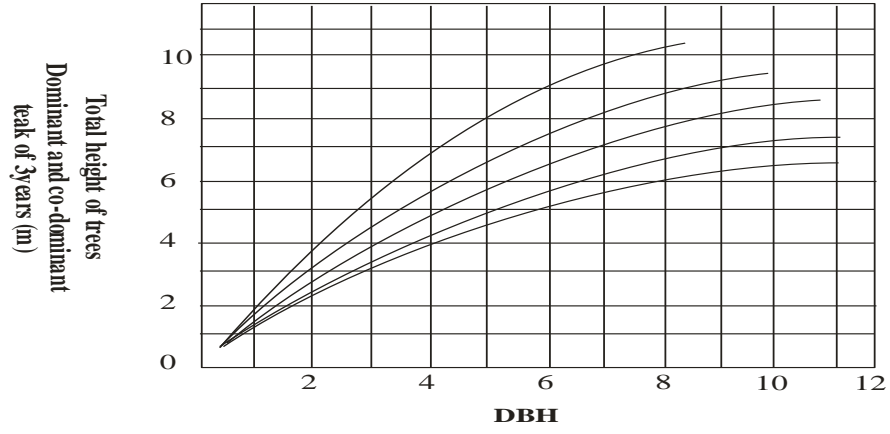

Fig. 1: Height of trees (Dominant and co-dominant teak of 3 years (m)

TABLE II

GROWTH PARAMETERS (TECTONIA GRANDIS) AGE 4 YEARS EVALUATED IN PLOT A AND PLOT B

Plot A

Plot B

\begin{tabular}{|c|c|c|c|c|c|}
\hline Tree No & $\begin{array}{l}\text { Total Height } \\
(\mathrm{m})\end{array}$ & $\mathrm{D}_{\mathrm{b}}(\mathrm{cm}$ & Tree No & $\begin{array}{l}\text { Total Height } \\
(\mathrm{m})\end{array}$ & $\mathrm{D}_{\mathrm{b}}(\mathrm{cm})$ \\
\hline 1 & 4.70 & 7.38 & 1 & 4.46 & 7.86 \\
\hline 2 & 5.55 & 10.53 & 2 & 5.40 & 8.66 \\
\hline 3 & 6.00 & 10.73 & 3 & 4.25 & 8.05 \\
\hline 4 & 7.70 & 16.23 & 4 & 6.40 & 8.85 \\
\hline 5 & 7.55 & 9.87 & 5 & 7.10 & 12.54 \\
\hline 6 & 6.25 & 9.90 & 6 & 5.75 & 9.96 \\
\hline 7 & 8.55 & 14.32 & 7 & 3.60 & 7.83 \\
\hline 8 & 5.75 & 10.47 & 8 & 9.05 & 12.56 \\
\hline 9 & 6.20 & 11.24 & 9 & 7.50 & 11.98 \\
\hline 10 & 5.25 & 10.60 & 10 & 8.30 & 9.80 \\
\hline 11 & 4.50 & 9.55 & 11 & 10.45 & 14.50 \\
\hline 12 & 4.00 & 9.71 & 12 & 8.62 & 12.54 \\
\hline 13 & 4.20 & 8.08 & 13 & 7.92 & 10.36 \\
\hline 14 & 6.20 & 9.00 & 14 & 8.30 & 15.28 \\
\hline 15 & 8.90 & 11.84 & 15 & 7.50 & 11.98 \\
\hline 16 & 6.75 & 11.04 & 16 & 6.40 & 9.01 \\
\hline 17 & 8.35 & 11.08 & 17 & 8.01 & 12.54 \\
\hline 18 & 5.70 & 9.61 & 18 & 8.50 & 15.88 \\
\hline 19 & 5.25 & 9.10 & 19 & 5.25 & 10.60 \\
\hline 20 & 8.85 & 14.80 & 20 & 6.00 & 9.96 \\
\hline 21 & 8.55 & 14.32 & 21 & 8.20 & 10.57 \\
\hline 22 & 10.45 & 14.50 & 22 & 5.30 & 11.27 \\
\hline 23 & 7.50 & 11.98 & 23 & 7.50 & 10.73 \\
\hline 24 & 8.55 & 14.32 & 24 & 6.10 & 10.47 \\
\hline 25 & 5.75 & 10.47 & 25 & 7.50 & 11.98 \\
\hline 26 & 6.20 & 11.24 & 26 & 8.55 & 14.32 \\
\hline 27 & 6.00 & 9.96 & 27 & 5.75 & 10.47 \\
\hline 28 & 8.20 & 10.57 & 28 & 6.20 & 11.24 \\
\hline 29 & 5.30 & 11.27 & 29 & 6.00 & 9.96 \\
\hline 30 & 9.50 & 12.60 & 30 & 8.20 & 10.57 \\
\hline 31 & 6.50 & 10.50 & 31 & 5.30 & 11.27 \\
\hline 32 & 8.20 & 11.74 & 32 & 9.50 & 12.60 \\
\hline 33 & 9.30 & 12.40 & 33 & 6.50 & 10.50 \\
\hline 34 & 10.50 & 13.43 & 34 & 8.20 & 11.74 \\
\hline 35 & 7.60 & 11.76 & 35 & 9.30 & 12.40 \\
\hline 36 & 7.55 & 9.90 & 36 & 10.50 & 13.43 \\
\hline 37 & 9.65 & 11.43 & 37 & 7.60 & 11.76 \\
\hline 38 & 10.27 & 10.56 & 38 & 6.39 & 8.32 \\
\hline
\end{tabular}

$D_{\text {b - Diameter at Breast Height (DBH) }}$ 


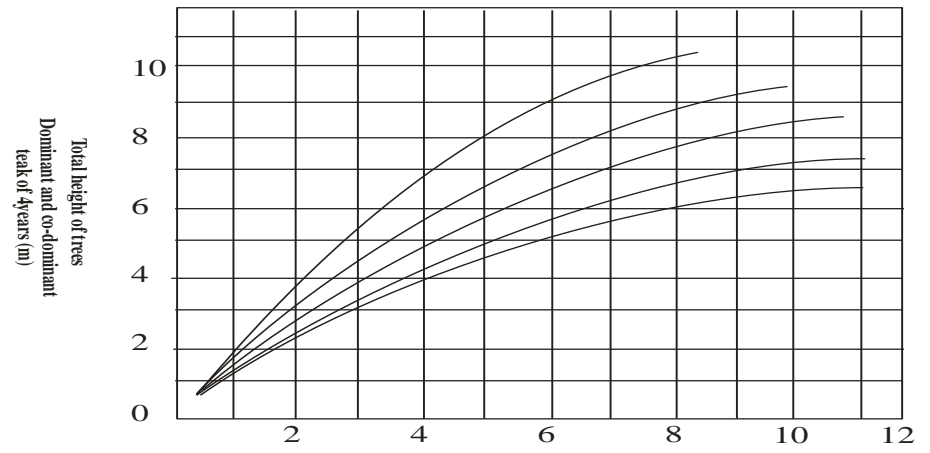

Fig. 2: Height of trees (Dominant and co-dominant teak of 4 years (m)

TABLE III:

GROWTH PARAMETERS (TECTONIA GRANDIS) AGE 5 YEARS EVALUATED IN PLOT A AND PLOT B

Plot A

Plot B

\begin{tabular}{|c|c|c|c|c|c|}
\hline Tree No & $\begin{array}{c}\text { Total Height } \\
(\mathrm{m})\end{array}$ & $\mathrm{D}_{\mathrm{b}}(\mathrm{cm})$ & Tree No & $\begin{array}{c}\text { Total Height } \\
(\mathrm{m})\end{array}$ & $\mathrm{D}_{\mathrm{b}}(\mathrm{cm})$ \\
\hline 1 & 9.35 & $\begin{array}{l}9.87 \\
\end{array}$ & 1 & 4.70 & 7.38 \\
\hline 2 & 8.20 & 9.55 & 2 & 5.55 & 10.53 \\
\hline 3 & 7.40 & 9.87 & 3 & 6.00 & 10.73 \\
\hline 4 & 8.40 & 12.25 & 4 & 7.70 & 16.23 \\
\hline 5 & 8.60 & 12.41 & 5 & 7.55 & 9.87 \\
\hline 6 & 10.70 & 14.90 & 6 & 6.25 & 9.90 \\
\hline 7 & 7.80 & 10.19 & 7 & 8.55 & 14.32 \\
\hline 8 & 9.10 & 12.32 & 8 & 5.75 & 10.47 \\
\hline 9 & 9.50 & 12.60 & 9 & 6.20 & 11.24 \\
\hline 10 & 6.50 & 10.50 & 10 & 5.25 & 10.60 \\
\hline 11 & 8.20 & 11.74 & 11 & 4.50 & 9.55 \\
\hline 12 & 10.35 & 10.03 & 12 & 4.00 & 9.71 \\
\hline 13 & 6.00 & 12.09 & 13 & 8.01 & 12.54 \\
\hline 14 & 6.70 & 13.15 & 14 & 8.50 & 15.88 \\
\hline 15 & 8.60 & 10.69 & 15 & 5.20 & 8.53 \\
\hline 16 & 9.70 & 13.53 & 16 & 6.00 & 9.96 \\
\hline 17 & 9.20 & 13.70 & 17 & 8.20 & 10.57 \\
\hline 18 & 12.30 & 13.40 & 18 & 5.30 & 11.27 \\
\hline 19 & 8.10 & 10.19 & 19 & 8.30 & 10.50 \\
\hline 20 & 11.60 & 12.90 & 20 & 6.10 & 10.47 \\
\hline 21 & 8.01 & 12.54 & 21 & 4.60 & 10.22 \\
\hline 22 & 10.35 & 10.03 & 22 & 7.50 & 11.98 \\
\hline 23 & 10.70 & 14.90 & 23 & 5.30 & 8.43 \\
\hline 24 & 5.30 & 11.27 & 24 & 7.50 & 11.98 \\
\hline 25 & 7.50 & 11.98 & 25 & 8.55 & 14.32 \\
\hline 26 & 8.55 & 14.32 & 26 & 5.75 & 10.47 \\
\hline 27 & 5.75 & 10.47 & 27 & 6.20 & 11.24 \\
\hline 28 & 6.20 & 11.24 & 28 & 6.00 & 9.96 \\
\hline 29 & 6.00 & 9.96 & 29 & 8.20 & 10.57 \\
\hline 30 & 8.20 & 10.57 & 30 & 5.30 & 11.27 \\
\hline 31 & 5.30 & 11.27 & 31 & 9.50 & 12.60 \\
\hline 32 & 9.50 & 12.60 & 32 & 6.50 & 10.50 \\
\hline 33 & 6.50 & 10.50 & 33 & 8.20 & 11.74 \\
\hline 34 & 8.20 & 11.74 & 34 & 5.55 & 10.53 \\
\hline 35 & 5.55 & 10.53 & 35 & 6.00 & 10.73 \\
\hline 36 & 6.00 & 10.73 & 36 & 7.70 & 16.23 \\
\hline 37 & 7.70 & 16.23 & 37 & 7.55 & 9.87 \\
\hline 38 & 7.55 & $\begin{array}{l}9.87 \\
\end{array}$ & 38 & 6.39 & 8.32 \\
\hline
\end{tabular}

$\mathbf{D}_{\mathbf{b} \text { - Diameter at Breast Height (DBH) }}$

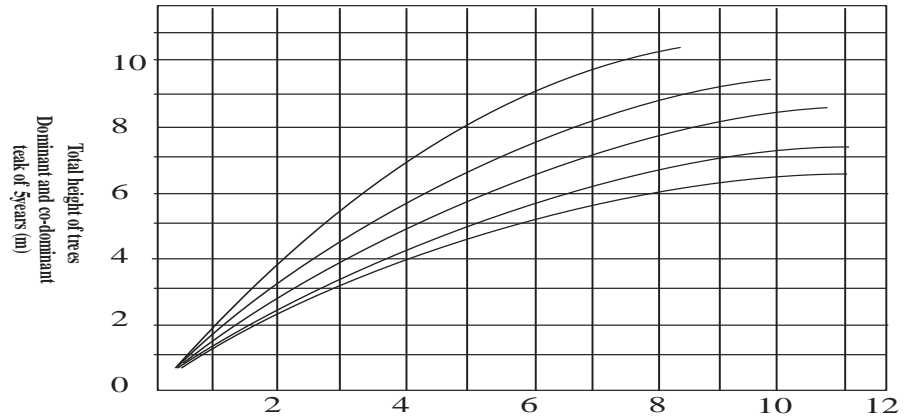

Fig. 3: Height of trees (Dominant and co-dominant teak of 5 years $(m)$

\section{CONCLUSION}

Considering the forest field inventory, it was confirmed that lack of silvicultural practices and negligence in tending forest species affected the growth rate of the species and supported by [13] [17]. Form reconnaissance survey and measurement carried out in the field it was found out that there was no significant growth difference in the six plots of uneven age. It was found out that plot 3 (4 years) had the largest basal area while plot 1 (3 years) had the least basal area. Considering volume estimation, plot 4 (4 years) had the largest volume while plot six (5 years) had the least volume. Also, plot 4 had the largest stand height of about $309.16 \mathrm{~m}$ while plot 6 (years) had the least stand height of about $249.90 \mathrm{~m}$. It was also observed that the study area was almost a relic forest and as such affected the growth parameters that were used for the estimation of basal area and volume. From true volume of the plot, plots of 4 years had the largest mean true volume of about $38.25 \mathrm{~m}^{3}$ while plot 1 and 2 ( 3 years) had the least mean true volume of about $30.36 \mathrm{~m}^{3}$.In the light of this investigation, it becomes necessary that there is need for government intervention in the plantation area would help in the rehabilitation of the almost relic forest. Also there is need to establish a data bank for the documentation of plantation information.

\section{REFERENCES}

[1] Society of American Foresters (1958) Forestry terminology: A glossary of technical terms, practice and products. English Language version, Soc. Am. For. Washington pg 97

[2] Akinsanmi F.A and Akindele, S.O (2002). Timber yield Assessment in the natural forest area of Oluwa Forest Reserve, Nigeria. The Nigeria Journal of Forestry Vol32 (1 \&2): 6-22

[3] Akinsanmi F.A (1967). The productivity of Teak in relation to site conditions in South- Western Nigeria. M. phil. Thesis, University of Ibadan, Ibadan. Nigeria $158 \mathrm{pp}$

[4] Adesoye, P.O (2002). Incorporating crown dimensions into stem Height and Basal area Growth Models for African White Wood (Triiplochiton scleroxylon). Ghana. J. Forestry. Vol 19 and 20 pp 45-46

[5] Chowdhury MQ, Rashid M and Alfred M (2008): Growth performance of teak (Tectona grandis linn. f.) coppice under different regime of canopy opening. Tropical Ecology 49 (2) 245-250.

[6] Enabor E.E 1981. Problems of Forest Resources Management in Nigeria, Agricultural Research Bulletin Vol. 2. Faculty of Agriculture and Forestry, University if Ibadan, Nigeria. $15 p$

[7] Enters T (2000) Site, technology and productivity of teak plantation in Southeast Asia unasylva. Vol. $51 \mathrm{pg} 207$

[8] FAO Corporate Document Repository, (1998). Title: Guildlines the management of tropical forests. http://www.fao.org/docrep/w8212e00.HTM. Collected on the 4th of February, 2009. 
[9] FAO (2000), Forest resources assessment definitions: copied from the FAO Co-operate Document Repository, Title Asia-Pacific forestry Commission: development of national-level criteria and indicators. http://www.fao.org/docrep/X6896e/x6896e00.htm

[10] FAO (2005a). Revised figures Butler A. Rhett (17th November, 2005). Nigeria has the worst deforestation rate, mongabay. Com

[11] FAO. Corporate Document Repository (1998). Title: Guidelines for The Management of tropical Forests. Docrep/w8212e/w8212e00. htm. Collected on the 4th of February, 2009

[12] FAO (1993). The challenge of sustainable forest management- what future for the world's forests? Sourced from the article : principles of sustainable tropical forest management where wood production is the primary objective. Docrep/w8212/w8212e04.html//what is forest management. Collected on the 4th February, 2009

[13] FAO. Corporate Document Repository (1998). Title: Guidelines for The Management of tropical Forests. Docrep/w8212e/w8212e00. HTM. Collected on the 4th of February, 2009

[14] FAO (1993). The challenge of sustainable forest management- what future for the world's forests? Sourced from the article : principles of sustainable tropical forest management where wood production is the primary objective. Docrep/w8212/w8212e04.html//what is forest management. Collected on the 4th February, 2009

[15] FORMECU [Forest Monitoring Evaluation and Coordinating Unit] (1991). Yield and potential revenue for Gmelina arborea plantations in Omo Rorest Reserve. FORMECU/STAS/PUB/NO. 10, 18pp

[16] Mahnut D and ayyeldiz (2005): the relationship between diameter at breast height $(\mathrm{DBH})$, total height, crown diameter in Lebanon cedars (Cedrus lebani A Rich) of yavsan mountains kahranan naras, turkey, Parkistan Journal of Biological sciences 8(9)1228-1232.

[17] Osho, J.S.A (1991). Matrix model for tree population projection in a tropical moist forest of South Western Nigeria. Ecological modeling 59; 247-255pp.

http://dx.doi.org/10.1016/0304-3800(91)90180-9 